\title{
Measurable residual disease in children with acute lymphoblastic leukemia treated with non-MRD based protocol, what we are missing, experience from tertiary care centre in central India
}

\author{
Pankaj Dwivedi ${ }^{1}$, Kishor Deshpande ${ }^{2}$, Atul Kapse ${ }^{1}$, Nitin Manvani ${ }^{1}$, Nilesh Dhole ${ }^{3}$, and \\ Anand Pathak ${ }^{2}$ \\ ${ }^{1}$ National caner institute nagpur \\ ${ }^{2}$ National cancer institute Nagpur \\ ${ }^{3}$ Homi Bhabha Cancer Hospital Varanasi India
}

April 3, 2021

\begin{abstract}
Age, presenting total leukocyte counts, steroid response and cytogenetics are known prognostic markers for acute lymphoblastic leukemia (ALL). Measurable Residual Disease (MRD) (or minimal residual disease) after induction chemotherapy is well accepted prognostic markers in childhood leukemia. In resource constrained countries evaluation of MRD either not widely available or increases the cost of treatment. We retrospectively analyzed data of patients, treated with non-MRD based protocol, to see correlation of known risk factors and risk groups with end of induction MRD. Children with acute lymphoblastic leukemia treated with IC-BFM 2002 (Non-MRD based protocol) and end of the induction MRD was done. Day15 bone marrow morphology and risk groups were significantly associated with MRD level. All standard risk patients except one had MRD negative. Significant number of intermediate risk group and high risk group had positive MRD. In resource constrained settings, MRD can be avoided in standard risk, but cannot be avoided in higher risk group for optimization of therapy.
\end{abstract}

Title: Measurable residual disease in children with acute lymphoblastic leukemia treated with nonMRD based protocol, what we are missing? : experience from tertiary care centre in central India

Author's name:

Pankaj Dwivedi $\mathrm{MD}^{1^{*}}$, Kishor Deshpande $\mathrm{MD}^{2}$, Atul Kapse $\mathrm{DNB}^{1}$, Nitin Manvani DNB ${ }^{1}$, Nilesh Dhole $\mathrm{MSc}^{3}$, Anand Pathak MD

1. Department of pediatric oncology National Cancer Institute Nagpur India

2. Department of pathology, National Cancer Institute Nagpur India

3. Department of onco-pathology Homi Bhabha Cancer Hospital Varanasi India

4. Department of medical oncology National Cancer Institute Nagpur India

*Correspondence: Dr.Pankaj Dwivedi MD Consultant Pediatric Oncology National Cancer Institute Nagpur India.

Contact Number: $+917122800400 /+919284001655$

E-mail address: drpankoo@gmail.com

Word count for Abstract: 157

Main text: 2006 
Number of tables: 06

Running title: MRD level in children treated with non-mrd protocol

Key words: Acute lymphoblastic leukemia, minimal residual disease, risk factors, risk stratification Abbreviations key

\begin{tabular}{ll}
\hline MRD & Measurable residual disease or minimal residual disease \\
\hline ALL & Acute lymphoblastic leukemia \\
NCI & National Cancer Institute \\
BFM & Berlin Frankfurt Munster \\
SR & Standard risk \\
PGR & Prednisolone good response \\
IR & Intermediate risk \\
HR & High risk \\
\hline
\end{tabular}

\section{Hosted file}

Abstract_pbc march 2021.pdf available at https://authorea.com/users/405623/articles/516555measurable-residual-disease-in-children-with-acute-lymphoblastic-leukemia-treated-withnon-mrd-based-protocol-what-we-are-missing-experience-from-tertiary-care-centre-incentral-india

\section{Hosted file}

manuscript_for_pbc_march_21.pdf available at https://authorea.com/users/405623/articles/ 516555-measurable-residual-disease-in-children-with-acute-lymphoblastic-leukemiatreated-with-non-mrd-based-protocol-what-we-are-missing-experience-from-tertiary-carecentre-in-central-india

\section{Hosted file}

Table 1.pdf available at https://authorea.com/users/405623/articles/516555-measurableresidual-disease-in-children-with-acute-lymphoblastic-leukemia-treated-with-non-mrdbased-protocol-what-we-are-missing-experience-from-tertiary-care-centre-in-central-india

\section{Hosted file}

Table 2.pdf available at https://authorea.com/users/405623/articles/516555-measurableresidual-disease-in-children-with-acute-lymphoblastic-leukemia-treated-with-non-mrdbased-protocol-what-we-are-missing-experience-from-tertiary-care-centre-in-central-india

\section{Hosted file}

Table 3.pdf available at https://authorea.com/users/405623/articles/516555-measurableresidual-disease-in-children-with-acute-lymphoblastic-leukemia-treated-with-non-mrdbased-protocol-what-we-are-missing-experience-from-tertiary-care-centre-in-central-india

\section{Hosted file}

Table 4.pdf available at https://authorea.com/users/405623/articles/516555-measurableresidual-disease-in-children-with-acute-lymphoblastic-leukemia-treated-with-non-mrdbased-protocol-what-we-are-missing-experience-from-tertiary-care-centre-in-central-india

\section{Hosted file}


Table 5.pdf available at https://authorea.com/users/405623/articles/516555-measurableresidual-disease-in-children-with-acute-lymphoblastic-leukemia-treated-with-non-mrdbased-protocol-what-we-are-missing-experience-from-tertiary-care-centre-in-central-india

\section{Hosted file}

Table 6 pbc.pdf available at https://authorea.com/users/405623/articles/516555-measurableresidual-disease-in-children-with-acute-lymphoblastic-leukemia-treated-with-non-mrd-

based-protocol-what-we-are-missing-experience-from-tertiary-care-centre-in-central-india 